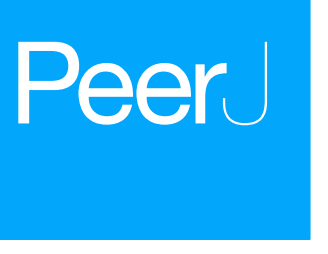

Submitted 22 April 2016 Accepted 22 June 2016 Published 9 August 2016

Corresponding author Mark J.F. Brown, mark.brown@rhul.ac.uk

Academic editor Giovanni Benelli

Additional Information and Declarations can be found on page 15

DOI 10.7717/peerj.2249

Copyright

2016 Brown et al.

Distributed under

Creative Commons CC-BY 4.0

\section{A horizon scan of future threats and opportunities for pollinators and pollination}

\author{
Mark J.F. Brown ${ }^{1}$, Lynn V. Dicks ${ }^{2}$, Robert J. Paxton ${ }^{3,4}$, \\ Katherine C.R. Baldock ${ }^{5,6}$, Andrew B. Barron ${ }^{7}$, Marie-Pierre Chauzat ${ }^{8}$, \\ Breno M. Freitas ${ }^{9}$, Dave Goulson ${ }^{10}$, Sarina Jepsen ${ }^{11}$, Claire Kremen ${ }^{12}$, Jilian Li $^{13}$, \\ Peter Neumann ${ }^{14}$, David E. Pattemore ${ }^{15}$, Simon G. Potts ${ }^{16}$, Oliver Schweiger ${ }^{17}$, \\ Colleen L. Seymour ${ }^{18,19}$ and Jane C. Stout ${ }^{20}$ \\ ${ }^{1}$ School of Biological Sciences, Royal Holloway University of London, Egham, United Kingdom \\ ${ }^{2}$ Conservation Science Group, Department of Zoology, University of Cambridge, Cambridge, \\ United Kingdom \\ ${ }^{3}$ Institute for Biology, Martin-Luther-University Halle-Wittenberg, Halle, Germany \\ ${ }^{4}$ iDiv, German Centre for Integrative Biodiversity Research Halle-Jena-Leipzig, Leipzig, Germany \\ ${ }^{5}$ School of Biological Sciences, University of Bristol, Bristol, United Kingdom \\ ${ }^{6}$ Cabot Institute, University of Bristol, Bristol, United Kingdom \\ ${ }^{7}$ Department of Biological Sciences, Macquarie University, Sydney, Australia \\ ${ }^{8}$ European reference laboratory for honeybee health, Unit of honeybee pathology \& Unit of coordination and \\ support to surveillance, ANSES, Maisons-Alfort Cedex, France \\ ${ }^{9}$ Departamento de Zootecnia, Centro de Ciências Agrárias, Universidade Federal do Ceará, Fortaleza Ceará, \\ Brazil \\ ${ }^{10}$ School of Life Sciences, University of Sussex, Falmer, United Kingdom \\ ${ }^{11}$ The Xerces Society for Invertebrate Conservation, Portland, OR, United States of America \\ ${ }^{12}$ Berkeley Food Institute, Environmental Sciences Policy and Management, University of California Berkeley, \\ Berkeley, CA, United States of America \\ ${ }^{13}$ Institute of Apicultural Research, Chinese Academy of Agricultural Sciences, Beijing, China \\ ${ }^{14}$ Institute of Bee Health, Vetsuisse Faculty, University of Bern, Bern, Switzerland \\ ${ }^{15}$ The New Zealand Institute for Plant \& Food Research Limited, Hamilton, New Zealand \\ ${ }^{16}$ Centre for Agri-Environmental Research, School of Agriculture, Policy and Development, \\ University of Reading, Reading, United Kingdom \\ ${ }^{17}$ Department of Community Ecology, Helmholtz Centre for Environmental Research-UFZ, Halle, Germany \\ ${ }^{18}$ South African National Biodiversity Institute, Kirstenbosch Research Centre, Claremont, South Africa \\ ${ }^{19}$ Percy FitzPatrick Institute of African Ornithology, DST/NRF Centre of Excellence, Department of Biological \\ Sciences, University of Cape Town, Rondebosch, South Africa \\ ${ }^{20}$ Botany, School of Natural Sciences, Trinity College Dublin, the University of Dublin, Dublin, Ireland
}

\section{ABSTRACT}

Background. Pollinators, which provide the agriculturally and ecologically essential service of pollination, are under threat at a global scale. Habitat loss and homogenisation, pesticides, parasites and pathogens, invasive species, and climate change have been identified as past and current threats to pollinators. Actions to mitigate these threats, e.g., agri-environment schemes and pesticide-use moratoriums, exist, but have largely been applied post-hoc. However, future sustainability of pollinators and the service they provide requires anticipation of potential threats and opportunities before they occur, enabling timely implementation of policy and practice to prevent, rather than mitigate, further pollinator declines. 
Methods. Using a horizon scanning approach we identified issues that are likely to impact pollinators, either positively or negatively, over the coming three decades.

Results. Our analysis highlights six high priority, and nine secondary issues. High priorities are: (1) corporate control of global agriculture, (2) novel systemic pesticides, (3) novel RNA viruses, (4) the development of new managed pollinators, (5) more frequent heatwaves and drought under climate change, and (6) the potential positive impact of reduced chemical use on pollinators in non-agricultural settings.

Discussion. While current pollinator management approaches are largely driven by mitigating past impacts, we present opportunities for pre-emptive practice, legislation, and policy to sustainably manage pollinators for future generations.

Subjects Conservation Biology, Ecology

Keywords Horizon scanning, Pollinator, Pollination, Ecosystem services, Conservation

\section{INTRODUCTION}

Pollinators provide the key ecosystem service of pollination to agricultural crops and wild plants, with $35 \%$ of global crop production relying to some degree on pollination (Klein et al., 2007), along with more than $85 \%$ of wild flowering plants (Ollerton, Winfree \& Tarrant, 2011). Consequently, declines in pollinators, which are occurring across the globe (Potts et al., 2010), may pose a significant threat to human and natural well-being. A suite of drivers, including habitat loss and homogenization (Kennedy et al., 2013), pesticides (Godfray et al., 2015), parasites and pathogens (e.g., Fürst et al., 2014; McMahon et al., 2015; Wilfert et al., 2016), invasive species (Stout \& Morales, 2009), and climate change (e.g., Kerr et al., 2015) have been identified as past and current threats to pollinators (Vanbergen \& The Insect Pollinator Initiative, 2013). Some actions to mitigate these threats, e.g., agri-environment schemes that provide forage and nesting resources (Batáry et al., 2015) and pesticide-use moratoriums to mitigate the potential impact of pesticides (Dicks, 2013), exist, but they have largely been applied post-hoc. While there is some evidence that such approaches might be mitigating pollinator losses (e.g., Carvalheiro et al., 2013), future sustainability of pollinators and the service they provide requires anticipation of potential threats and opportunities before they occur, enabling timely implementation of policy and practice to prevent, rather than mitigate, further pollinator declines.

One approach that can be used to anticipate future threats and opportunities for pollinators is the process of horizon scanning. Horizon scanning, a systematic technique to identify future threats or opportunities, is an important policy tool used in government and business to manage and proactively respond to upcoming threats and opportunities (Cook et al., 2014). In the last decade, horizon scanning has increasingly been applied to support environmental decision-making and inform policy and research on specific issues such as invasive species risk (Roy et al., 2014), management of particular geographic regions (Kennicutt et al., 2014) or threats to particular taxa (Fox et al., 2015). Proactive responses that pre-empt environmental risks are likely to be cheaper in the long term than reactive 


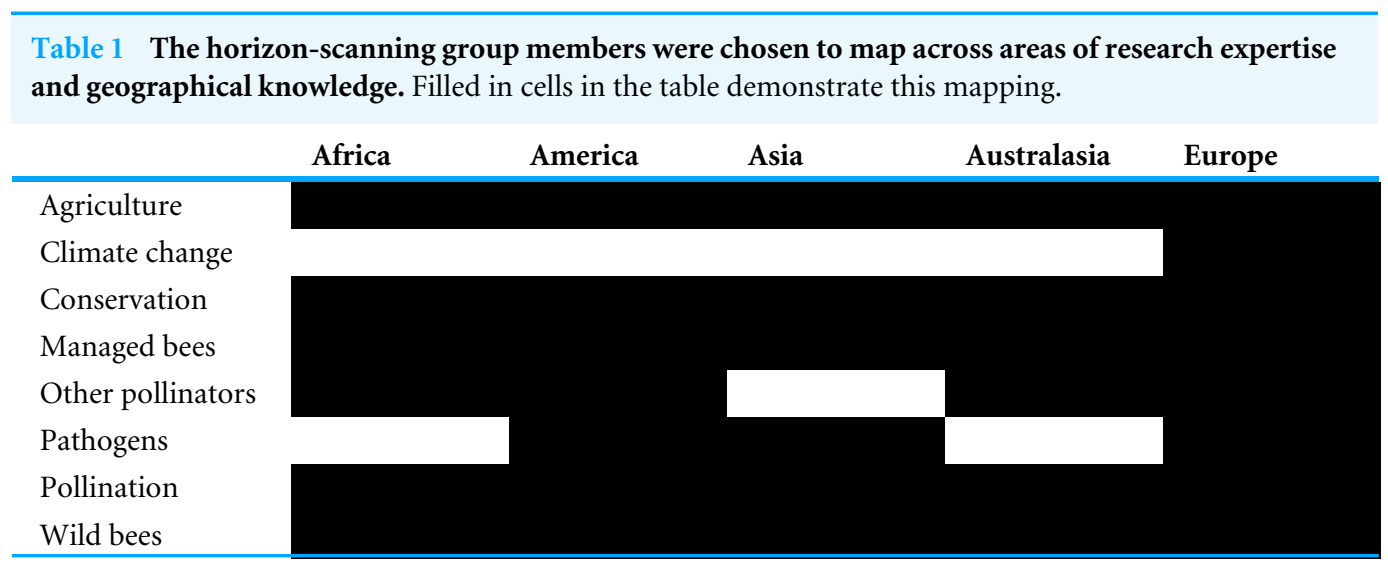

responses (e.g., Drechsler, Eppink \& Wätzold, 2011) and potentially enable avoidance of substantial costs (Hulme et al., 2009).

Pollinator decline is one of the highest profile global environmental issues of the 21 st century, as demonstrated through its selection by the International Platform on Biodiversity and Ecosystem Services (IPBES) as the subject of its first major assessment report (Gilbert, 2014). With governments around the world focused on this issue, and several producing national policies which largely focus around past and current threats, it is timely to identify forthcoming impacts on pollinators, both positive and negative, which may not yet be fully recognised by policy or research. Here we used a global horizon scanning team to identify potential future threats and opportunities for pollinators.

\section{METHODS}

We followed a Horizon Scanning approach based on the Delphi method (Sutherland et al., 2016). The same approach has been used since 2010 to generate global horizon scans for conservation (Sutherland et al., 2016), and thus it provides a reliable and accepted methodology. The exercise was carried out by a core group of 17 pollinator experts (the authors), balanced across area of expertise and geographic knowledge. Experts were drawn from NGOs, research institutes, and universities. One member from the agrochemical industry accepted, but withdrew before the first stage of the process (see below) was completed. Table 1 shows how the group maps on to the two criteria of expertise and geography, and demonstrates strong coverage within the horizon-scanning group.

\section{Selecting issues}

Each person in the team consulted their networks and collected up to five potential horizon issues for consideration; 55 people (see 'Acknowledgements'), in addition to the 17 experts, were consulted during this process. We searched for issues that were poorly known and considered likely to have a substantial impact on wild or managed pollinators (including insects, birds, mammals, and reptiles), either positive or negative, during the next one to 30 years. A 'substantial' impact could have a high magnitude, or take place over a large area, or both. 
A long list of 60 issues, with associated references, was compiled (Table 2, Table S1) and sent to all core participants for a first round of anonymous scoring. Where the same issues had been identified by more than one member of the core group, these issues were grouped as one. Participants scored each issue from 1 (well known, unlikely to have substantial impact on pollinators) to 1,000 (poorly known, very likely to have substantial impact on pollinators). From these scores, we produced a ranked list of topics for each participant (the highest scored issue was given a rank of 1), and calculated the median rank for each topic (Table 2). Each person also stated whether they had previously heard of each issue or not.

\section{Refining to a shortlist of priorities}

The 28 issues with the lowest median ranks were retained, and participants had a chance to retain others they felt strongly should not be dismissed at this stage (no issues were brought back). Two participants were assigned to each of the 28 retained issues to research its technical details, likelihood, and potential impacts. These were not the same people who had suggested the issue.

Ten of the participants convened in Paola, Malta, in November 2015. We discussed each of the 28 issues in turn, with the constraint that the individual who suggested an issue was not the first to contribute to its discussion. All participants could see the median ranks and the percentage of the group who had heard of each issue (given as 'originality value' in Table 2), from round 1 . Some issues were modified during this discussion. After each issue was discussed, participants independently and privately scored between 1 and 1,000 as previously described. The 'originality value' was used as a guide for scoring, although we were aware that, as the participants were all pollinator experts, it was unlikely to represent familiarity with these issues in the wider policy and research communities.

The remaining seven participants unable to attend the meeting took part in the process remotely, by submitting their research notes for issues they had been assigned (these were provided to each participant in printed form), and re-scoring independently after reading a detailed written account of the issues discussed.

The list of 15 issues presented here comprises those with the highest median ranks from the second round of scoring (Table 3). They are divided into High Priority and Secondary Priority issues (HPI, and SPI, respectively) because there was a clear break in the rankings among the top 15 issues, between the top six and the following nine. One issue ("Sanitary and genetic issues raised by international trade and globalization") was removed from the final priority list despite having been ranked joint 13th by its median rank. While clearly important, the group agreed in the final stage that this was a current, well-known issue, and not an emerging issue on the horizon.

\section{RESULTS}

Using a modified Delphi process, we identified 60 initial issues of interest (Table 2, Table S1), which reduced to six high priority issues and nine secondary priority issues (Table 3 ). These issues can be partially mapped onto areas previously identified as being important causes of pollinator decline, e.g., agricultural practices (Fig. 1, Table 4). However, the issues we identified are largely distinct from past and current drivers of pollinator abundance, and 
Table 2 The results of the first round of voting on the horizon-scanning issues. Each issue is listed with its median rank (low rank = most strongly voted for as a horizon issue) and its originality score ( $0=$ not heard of, $1=$ completely familiar)(see Methods for details). The number in the left column is simply the order in which issues were compiled.

\begin{tabular}{|c|c|c|c|}
\hline \# & Title & Median rank & Originality value \\
\hline 1 & Sulfoximine, a novel systemic class of insecticides & 2 & 0.71 \\
\hline 2 & $\begin{array}{l}\text { The effect of chemical use on pollinators in non-agricultural } \\
\text { settings }\end{array}$ & 15 & 0.94 \\
\hline 3 & Increasing use of fungicides & 24 & 1.00 \\
\hline 4 & Aluminium & 44 & 0.29 \\
\hline 5 & $\begin{array}{l}\text { Potential non-target effects of nanoparticle pesticides on } \\
\text { crop visiting insect pollinators }\end{array}$ & 22 & 0.53 \\
\hline 6 & Below-ground effects on plant-pollinator interactions & 26 & 0.41 \\
\hline 7 & Diffuse pollution: overlooked and underestimated? & 27 & 0.47 \\
\hline 8 & $\begin{array}{l}\text { Policy and market factors exacerbate simplification of } \\
\text { agricultural landscapes }\end{array}$ & 15 & 0.94 \\
\hline 9 & Soybean crop expansion worldwide & 36 & 0.29 \\
\hline 10 & Reduction or even removal of glyphosate & 39 & 0.53 \\
\hline 11 & $\begin{array}{l}\text { Potential loss of floral resources for pollinators within } \\
\text { and adjacent to agricultural lands through adoption of } \\
\text { forthcoming 'next generation' genetically engineered crops } \\
\text { and associated herbicide use }\end{array}$ & 11 & 0.76 \\
\hline 12 & $\begin{array}{l}\text { Agricultural policy leading to } \\
\text { intensification/abandonment/reforestation }\end{array}$ & 35 & 1.00 \\
\hline 13 & $\begin{array}{l}\text { Land sparing (setting aside land for biodiversity } \\
\text { conservation and intensifying production on remaining } \\
\text { land) }\end{array}$ & 27 & 0.88 \\
\hline 14 & $\begin{array}{l}\text { Lack of investment in research into sustainable farming } \\
\text { methods }\end{array}$ & 29 & 0.94 \\
\hline 15 & $\begin{array}{l}\text { Risks and opportunities of cutting pollinators out of food } \\
\text { production }\end{array}$ & 7 & 0.82 \\
\hline 16 & $\begin{array}{l}\text { Precision agriculture could improve pollination \& reduce } \\
\text { harm to pollinators }\end{array}$ & 33 & 0.47 \\
\hline 17 & $\begin{array}{l}\text { Corporate farming could see effective alternative } \\
\text { pollination systems adopted rapidly }\end{array}$ & 33 & 0.53 \\
\hline 18 & $\begin{array}{l}\text { New positions open for alternative pollinators: must have } \\
\text { good credentials }\end{array}$ & 21 & 0.82 \\
\hline 19 & $\begin{array}{l}\text { Possible horticultural industry responses to pollinator } \\
\text { limitation: bees in boxes }\end{array}$ & 39 & 0.71 \\
\hline 20 & GMO honey bees: a boon to pollination & 33 & 0.35 \\
\hline 21 & Natural selection and apiculture: breeding & 42 & 0.82 \\
\hline 22 & Entomovectoring & 34 & 0.76 \\
\hline 23 & Reduced budgets for public greenspace management & 34 & 0.65 \\
\hline 24 & Green roofs as potential pollinator habitat & 40 & 0.82 \\
\hline 25 & $\begin{array}{l}\text { Climate change causing changes in crop distribution, } \\
\text { leading to changes in managed pollinator distributions }\end{array}$ & 31 & 0.59 \\
\hline 26 & $\begin{array}{l}\text { Socioeconomic drivers of change in flowering crops: } \\
\text { unpredictable outcomes }\end{array}$ & 24 & 0.76 \\
\hline
\end{tabular}




\section{Table 2 (continued)}

\begin{tabular}{|c|c|c|c|}
\hline$\#$ & Title & Median rank & Originality value \\
\hline 27 & Benefits to pollinators from water quality protection & 24 & 0.41 \\
\hline 28 & $\begin{array}{l}\text { Treatments for managed honeybee bacterial diseases using } \\
\text { phage therapy }\end{array}$ & 32 & 0.24 \\
\hline 29 & $\begin{array}{l}\text { Novel pathogens: a threat to many bee species and } \\
\text { pollination }\end{array}$ & 19 & 0.82 \\
\hline 30 & Pollinators as pathways for pathogens & 21 & 0.88 \\
\hline 31 & $\begin{array}{l}\text { Reductions in pollinator species richness may drive } \\
\text { epidemics }\end{array}$ & 15 & 0.29 \\
\hline 32 & Honeybee viruses & 36 & 1.00 \\
\hline 33 & $\begin{array}{l}\text { Bacterial diseases: American foulbrood \& European } \\
\text { foulbrood }\end{array}$ & 53 & 0.94 \\
\hline 34 & New emerging diseases: small hive beetle Aethina tumida & 39 & 0.88 \\
\hline 35 & New emerging diseases: Tropilaelaps spp. & 29 & 0.53 \\
\hline 36 & Varroa 2.0 & 28 & 0.41 \\
\hline 37 & Infection with Nosema spp. & 41 & 0.71 \\
\hline 38 & Co-exposure between pesticides and pathogens & 22 & 1.00 \\
\hline 39 & $\begin{array}{l}\text { Sanitary and genetic issues raised by international trade and } \\
\text { globalization }\end{array}$ & 21 & 1.00 \\
\hline 40 & $\begin{array}{l}\text { Climate change: altering pathogen epidemiology to the } \\
\text { detriment of pollinators }\end{array}$ & 15 & 0.59 \\
\hline 41 & $\begin{array}{l}\text { Changes in nutritional value of plants as a consequence of } \\
\text { elevated atmospheric } \mathrm{CO} 2 \text { and pollution associated with } \\
\text { human activities }\end{array}$ & 19 & 0.41 \\
\hline 42 & $\begin{array}{l}\text { Increasing frequency of heatwaves and droughts may drive } \\
\text { pollinator declines }\end{array}$ & 15 & 0.88 \\
\hline 43 & Impact of climate change on plant-pollinator interactions & 24 & 0.88 \\
\hline 44 & $\begin{array}{l}\text { Impact of climate change on pollinator-pollinator } \\
\text { interactions }\end{array}$ & 30 & 0.47 \\
\hline 45 & $\begin{array}{l}\text { Decline and eventual disappearance of bumblebees due to } \\
\text { climate change }\end{array}$ & 38 & 0.94 \\
\hline 46 & $\begin{array}{l}\text { The impact of invasive alien commercial honeybees on } \\
\text { native bees in Asia }\end{array}$ & 17 & 0.76 \\
\hline 47 & The spread of Apis cerana & 33 & 0.53 \\
\hline 48 & Use of managed bees to reduce human-wildlife conflict & 42 & 0.59 \\
\hline 49 & Substances that affect pollinator memory & 36 & 0.82 \\
\hline 50 & $\begin{array}{l}\text { National and global monitoring: limited progress without } \\
\text { them }\end{array}$ & 24 & 0.88 \\
\hline 51 & Altered evolutionary trajectories in plants and pollinators & 22 & 0.47 \\
\hline 52 & Environmental and ecological effect of Dams & 51 & 0.50 \\
\hline 53 & The bee band-wagon & 24 & 0.65 \\
\hline 54 & The media & 43 & 0.82 \\
\hline 55 & Focus on technology and commercialisation in science funding & 24 & 0.82 \\
\hline 56 & Destruction of roosting sites for pollinating bats worldwide & 18 & 0.41 \\
\hline 57 & Reproductive division of labor and susceptibility to stressors & 45 & 0.59 \\
\hline 58 & Gene drive technology to eradicate invasive pollinators & 21 & 0.18 \\
\hline 59 & Impacts of IPBES pollinators assessment & 24 & 0.71 \\
\hline 60 & Extinctions of flower-visiting birds & 27 & 0.82 \\
\hline
\end{tabular}


Table 3 The final results of the second round of voting on the reduced list of horizon-scanning issues. Each issue is shown with its median rank. Note that the title of some issues were changed based on discussion prior to the second round of voting.

\begin{tabular}{|c|c|c|}
\hline \# & Title & Median rank \\
\hline 1 & $\begin{array}{l}\text { Sulfoximine, a novel systemic class of insec- } \\
\text { ticides }\end{array}$ & 5 \\
\hline 2 & $\begin{array}{l}\text { Positive effects of reduced chemical use on } \\
\text { pollinators in non-agricultural settings [new } \\
\text { title] }\end{array}$ & 7 \\
\hline 3 & Increasing use of fungicides & 12 \\
\hline 5 & $\begin{array}{l}\text { Potential non-target effects of nanoparticle } \\
\text { pesticides on crop visiting insect pollinators }\end{array}$ & 11 \\
\hline 6 & $\begin{array}{l}\text { Below-ground effects on plant-pollinator } \\
\text { interactions }\end{array}$ & 16 \\
\hline 8 & $\begin{array}{l}\text { Corporate control of agriculture at the } \\
\text { global scale [new title] }\end{array}$ & 4 \\
\hline 11 & $\begin{array}{l}\text { Potential loss of floral resources } \\
\text { for pollinators within and } \\
\text { adjacent to agricultural lands through } \\
\text { adoption of forthcoming 'next generation' } \\
\text { genetically engineered crops and associated } \\
\text { herbicide use }\end{array}$ & 16 \\
\hline 15 & $\begin{array}{l}\text { Risks and opportunities of cutting pollina- } \\
\text { tors out of food production }\end{array}$ & 12 \\
\hline 18 & $\begin{array}{l}\text { Increased diversity of managed pollinator } \\
\text { species [new title] }\end{array}$ & 6 \\
\hline 26 & $\begin{array}{l}\text { Socioeconomic drivers of change in flower- } \\
\text { ing crops: unpredictable outcomes }\end{array}$ & 20 \\
\hline 27 & $\begin{array}{l}\text { Benefits to pollinators from water quality } \\
\text { protection }\end{array}$ & 18 \\
\hline 29 & Novel emerging RNA viruses [new title] & 5 \\
\hline 30 & Pollinators as pathways for pathogens & 13 \\
\hline 31 & $\begin{array}{l}\text { Reductions in pollinator species richness } \\
\text { may drive epidemics }\end{array}$ & 13 \\
\hline 38 & $\begin{array}{l}\text { Co-exposure between pesticides and } \\
\text { pathogens }\end{array}$ & 22 \\
\hline 39 & $\begin{array}{l}\text { Sanitary and genetic issues raised by inter- } \\
\text { national trade and globalization }\end{array}$ & 13 \\
\hline 40 & $\begin{array}{l}\text { Climate change: altering pathogen epidemi- } \\
\text { ology to the detriment of pollinators }\end{array}$ & 14 \\
\hline 41 & $\begin{array}{l}\text { Changes in nutritional value of plants as a } \\
\text { consequence of elevated atmospheric } \mathrm{CO} 2 \\
\text { and pollution associated with human activ- } \\
\text { ities }\end{array}$ & 21 \\
\hline 42 & $\begin{array}{l}\text { Effects of extreme weather events under cli- } \\
\text { mate change [new title] }\end{array}$ & 6 \\
\hline 43 & $\begin{array}{l}\text { Impact of climate change on plant- } \\
\text { pollinator interactions }\end{array}$ & 20 \\
\hline
\end{tabular}




\begin{tabular}{lll} 
Table 3 (continued) & Median rank \\
\hline 4 & Title & 13 \\
\hline 50 & $\begin{array}{l}\text { The impact of non-native managed pollina- } \\
\text { tors on native bee communities in Asia }\end{array}$ & 19 \\
\hline 51 & $\begin{array}{l}\text { National and global monitoring: limited } \\
\text { progress without them }\end{array}$ & 25 \\
\hline 53 & $\begin{array}{l}\text { Altered evolutionary trajectories in plants } \\
\text { and pollinators }\end{array}$ & 26 \\
\hline 55 & $\begin{array}{l}\text { The bee band-wagon } \\
\text { Focus on technology and commercialisation } \\
\text { in science funding }\end{array}$ & 23 \\
\hline 56 & $\begin{array}{l}\text { Destruction of bat roosts worldwide [new } \\
\text { title] } \\
\text { Gene drive technology to eradicate invasive } \\
\text { pollinators }\end{array}$ & 15 \\
\hline 59 & Impacts of IPBES pollinators assessment & 25 \\
\hline
\end{tabular}

require distinct policy and practices to minimize the threat and maximise the opportunities they present (Table 4). As is standard for a horizon scanning process, the identified issues are presented in rank order below, with the highest ranked issue first.

\section{HPI-1: corporate control of agriculture at the global scale}

Consolidation in agri-food industries has led to unprecedented control over land access, land use and agricultural practices by a small number of companies (Worldwatch Institute, 2013). A newer trend is transnational land deals for crop production, which now occupy over 40 million hectares (http://www.landmatrix.org/en/), including areas of Brazil for soybean export to China, and West Africa for rubber and palm oil. Agri-food industries operating at scale tend to promote homogeneous production systems, which is rapidly changing landscapes, especially in the southern hemisphere (Laurance et al., 2014) in a way that could substantially reduce the diversity and abundance of native pollinators. From an opportunity perspective, large-scale control over agricultural practices could, under appropriate management practices, enable sustainable pollinator management to optimize pollination with respect to consumer demands.

\section{HPI-2: sulfoximine, a novel systemic class of insecticides}

Sulfoximines are a new class of insecticide that resemble neonicotinoids in mode of action, yet differ sufficiently to prevent cross-resistance (Sparks et al., 2013). The first sulfoximine to be marketed is Sulfoxaflor. In spray formulation, it is rapidly being registered for widespread crop use in countries across the globe, to combat rising resistance to neonicotinoids (Bass et al., 2015). If, as is likely, sulfoximines are next registered as seed treatments, they may soon replace neonicotinoids over vast geographic areas (Simon-Delso et al., 2015). Neonicotinoids have sub-lethal effects on wild pollinators (e.g., Rundlöff et al., 2015), which may be generated through impacts on neural processes and immunity (e.g., Di Prisco et al., 2013), but those of sulfoximines have not been studied. Seed treatments are particularly likely to generate sub-lethal effects broadly, since they are applied prophylactically, rather 
Table 4 The relationship between horizon scanning issues, past problems and actions, and future responses. The relationship between responses to current or past issues (column 1), identified horizon issues grouped by overarching driver (column 2), and potential pro-active responses to these issues (column 3).

Current responses, suggested or enacted, to related non-horizon issues

\section{Habitat loss \& homogenisation}

Agri-environmental schemes; paying farmers to cover the costs of pollinator conservation measures so as to connect habitat patches to allow pollinator movement

Habitat protection

\section{Pesticides}

Pesticide risk assessment and regulation

Reduce pesticide use (for example, through In-

tegrated Pest Management)

Reduced exposure through technological inovation (e.g., minimise spray dust and drift)

\section{Parasites \& Pathogens}

The World Organization for Animal health (OIE http://www.oie.int) regulations for transport and screening of bees
Reduced impacts in nonagricultural settings

Nanoparticle pesticides

Increasing fungicide use

\section{Horizon issues}

HPI-1, SPI-9

Corporate control of agriculture at global scale

Destruction of bat roosts

HPI-2, HPI-6, SPI-1, SPI-2

Sulfoximine pesticides

HPI-3, SPI-5, SPI-6

New RNA viruses

Reduced pollinator richness

drives epidemics

Pollinators as disease vectors

\section{Potential responses to horizon issues}

Consumer-led certification schemes focused on pollinators

Corporate Social Responsibility commitments to pollinators (or wider biodiversity)

Legal protection of bat roosts as sanctuaries, especially in the tropics

Education of land owners about bat conservation

Research to assess the impact of bat declines on pollination services

Pesticide risk assessment and regulation urgently needs to incorporate chronic, sub-lethal, indirect, and interactive impacts and in-field realistic trials using a range of pollinator species

Monitor impacts of pesticide use in nonagricultural setting

Research into impacts of nanoparticles on pollinators

Global and national campaigns to reduce and replace chemical usage in urban and suburban areas

A coordinated international network for detecting the emergence of viral diseases of managed pollinators

Consider methods of pollinator management in plant disease control 


\section{Potential responses to horizon issues}

$\begin{array}{ll}\text { Climate change } & \text { HPI-5, SPI-8 } \\ \text { Connect habitat patches to allow pollinator } & \text { Effects of extreme weather events }\end{array}$

movement

Effects of extreme weather events

Diversify farming practices, such as through

crop rotation, to reduce risk treme temperatures, rainfall or drought (e.g., planting flower strips with drought resistant flower species)

Develop and use alternative climate resilient managed pollinator species

Altered pathogen epidemiology

Predict changes in distribution of pathogens under climate change

\section{Invasive Species}

SPI-7

Listing potentially invasive species

Invasive bees in Asia

Prevent or regulate use of non-native managed bee species, especially Bombus terrestris, which is known to be invasive

Surveillance in at risk areas

Regulations on international trade and move-

ments

Increased diversity of managed pollinators (HPI-4)

Cutting pollinators out of food production (SPI-3)

Impacts of IPBES pollinators assessment (SPI-4)
Identify candidate wild pollinators for management

Risk assessment and regulation of movement around deployment of new managed pollinator species

Re-calibrate conservation to recognise the inherent value of pollinators, outside food production

Quantify range of risks and benefits to sustainable food production

Incorporate outputs into national and international policies relevant to pollinators including agriculture, pesticide, conservation and plan- 


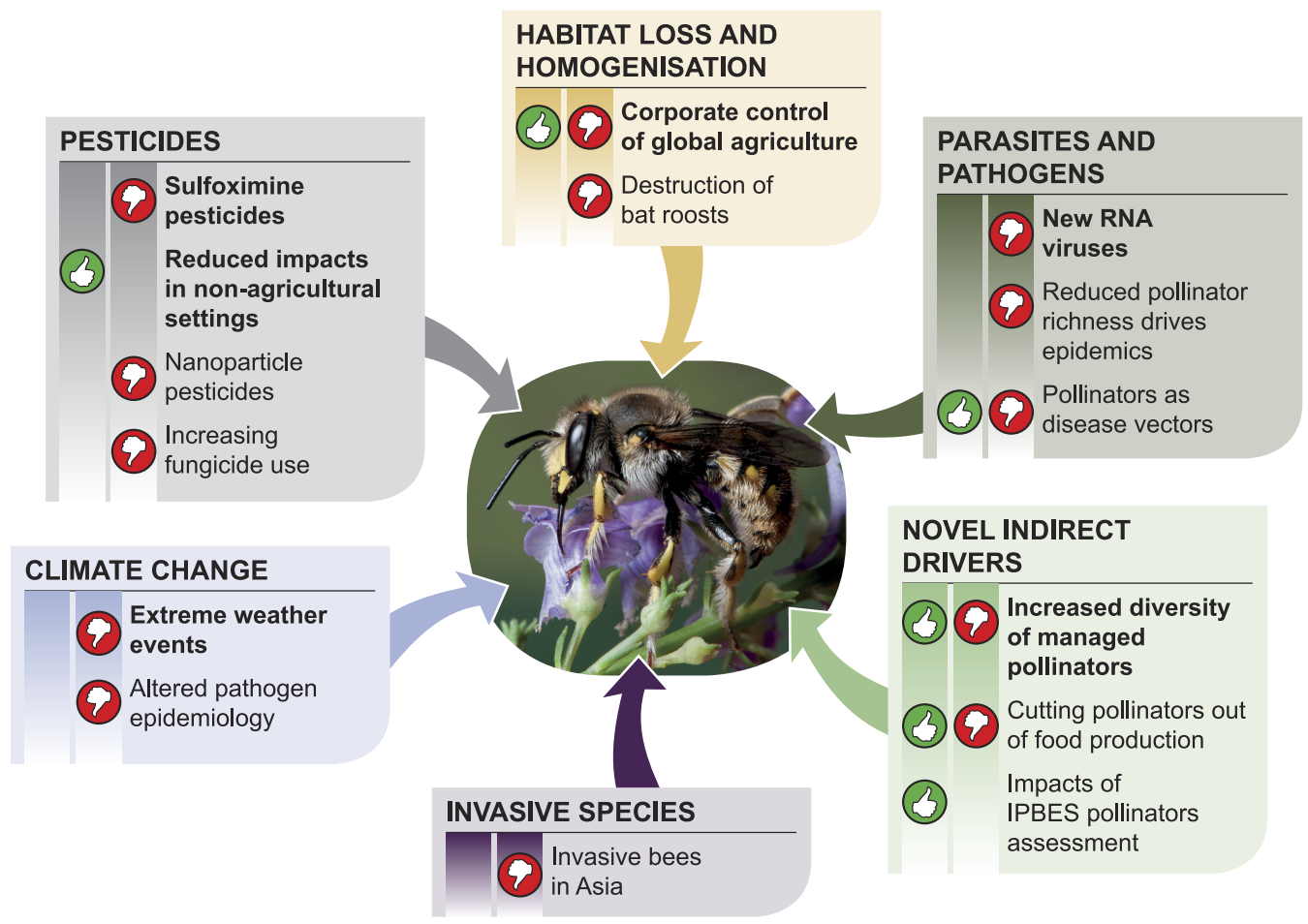

Figure 1 A schematic showing how the horizon scanning issues for pollinators map onto existing known drivers of pollinator decline, following Vanbergen \& The Insect Pollinator Initiative (2013), and novel drivers with positive or negative opportunities.

than sprayed at specific times (where usage may be modified to reduce or avoid impacts on pollinators). Thus, the rapid proliferation of a new systemic, neuroactive insecticide without sufficient testing for sub-lethal effects is a grave concern, particularly if new formulations such as seed treatments arise.

\section{HPI-3: new emerging RNA viruses}

Emerging infectious diseases-some transmitted by exotic ectoparasitic Varroa destructor mites-are considered major causes of colony decline for the most abundant commercial pollinator, the Western honey bee (Apis mellifera). Such diseases are shared with, and likely spill over into, wild pollinators (Fürst et al., 2014). Chief among them are RNA viruses, whose high mutation and recombination rates make them particularly likely to cross host backgrounds (Manley, Boots \& Wilfert, 2015). There is substantial risk of novel viral diseases emerging with elevated virulence, more efficient transmission and broad host range. The threat to both wild and managed pollinators is exacerbated by transport of managed pollinators to new locations, which may bring RNA viruses into contact with novel vectors (Roberts, Anderson \& Tay, 2015). 


\section{HPI-4: increased diversity of managed pollinator species}

Managed pollinators can replace or augment wild pollinators, but currently very few species are employed-most commonly Apis mellifera and, to a lesser extent, some bumblebees, stingless bees, and solitary bees (Free, 1993; Delaplane \& Mayer, 2000). Diversifying the species managed for pollination could enhance pollination in crops that either require specialist pollinators or do not receive optimal service from existing managed species; provide insurance against perturbations in the supply of existing species; and enable use of native species in regions where existing managed species are not native. It also represents a business opportunity. Developing alternative managed pollinators requires biological and technical knowledge about the focal species, to ensure reliable supplies for growers. Risks associated with deploying new species, including parasite transmission, competition with local pollinators, introgression with the local gene pool, and ecosystem level impacts (Stout \& Morales, 2009), require proactive risk assessment and regulation.

\section{HPI-5: effects of extreme weather events under climate change}

Effects of gradually changing climate on pollinators are increasingly well characterised, while the impacts of extreme events are poorly understood. Projected increases in frequency, magnitude, or intensity of, e.g., heatwaves and droughts are very likely across substantial parts of the globe (IPCC Summary for Policymakers, 2013). Heatwaves and droughts can affect pollinators directly, or indirectly by generating resource bottlenecks (Takkis et al., 2015). There is evidence that such weather patterns can lead to local extinction of pollinators (Rasmont \& Iserbyt, 2012; Oliver et al., 2015) potentially leading to the breakdown of plantpollinator relationships (Harrison, 2000). Greater knowledge of the relative importance of different extreme events is urgently needed to future-proof pollinator-friendly habitat management.

\section{HPI-6: positive effects of reduced chemical use on pollinators in non-agricultural settings}

Chemicals that have negative impacts on pollinators are widely used in urban and suburban areas, and in the wider landscape (e.g., golf courses). Recent recognition of the value of such areas for pollinators (Baldock et al., 2015) provides an opportunity to increase awareness of chemical use, and drive successful 'reduce and replace' campaigns. The potential for large-scale reduction in chemical use across ever-growing urban and suburban areas could have significant positive impacts on insect pollinators (Muratet \& Fontaine, 2015).

\section{SPI-1: potential non-target effects of nanoparticle pesticides on crop visiting insect pollinators}

Nanoparticle pesticide use is rapidly expanding (Sekhon, 2014), yet non-target effects have not been evaluated, and this technology may evade existing pesticide regulatory processes. Though major knowledge gaps exist, nanoparticle pesticides may adversely affect crop-visiting pollinators.

\section{SPI-2: increasing use of fungicides}

Fungicide use is expected to increase with higher summer rainfall, which has been predicted for many regions under climate change scenarios (IPCC Summary for Policymakers, 2013). 
Current risk assessments for fungicides fail to capture sub-lethal and indirect impacts (e.g., on bee gut flora and fungi in pollen stores, synergies between fungicides and insecticides, and elevated susceptibility to disease (Pettis et al., 2013)).

\section{SPI-3: risks and opportunities of cutting pollinators out of food production}

Plant breeding technology can produce crop varieties that do not require biotic pollination (Mazzucato et al., 2015). Wide uptake of this technology could stabilize yields and reduce costs, but could further entrench the pollinator crisis by removing the imperative for pollinator protection and threatening the viability of remaining pollinator-dependent crops.

\section{SPI-4: impacts of IPBES pollinators assessment}

The Intergovernmental Platform on Biodiversity and Ecosystem Services' 2016 global assessment "Pollinators, Pollination and Food Production" (IPBES, 2016) is a critical evaluation of evidence on the status, value and threats to pollinators and pollination worldwide. It could galvanise or inform substantial new actions by governments, practitioners and researchers.

\section{SPI-5: pollinators as pathways for pathogens}

While visiting flowers, pollinators can also transmit plant and pollinator diseases (McArt et al., 2014). Crop industries concerned about pollinator-mediated disease spread could enact restrictions on movements of managed pollinators, providing economic incentive to prioritise the use of local wild pollinators.

\section{SPI-6: reductions in pollinator species richness may drive epidemics}

Infectious disease transmission involves interactions among networks of species. The inverse relationship between host species diversity and disease transmission (Civitello et al., 2015) could drive disease epidemics as pollinator diversity declines.

\section{SPI-7: the impact of non-native managed pollinators on native bee communities in Asia}

The commercial importation of European Bombus terrestris (He et al., 2013) is very likely to negatively impact bumblebee communities in China, the global centre of bumblebee species diversity, as it has in other areas (e.g., Morales et al., 2013). The eight native honey bee species are increasingly likely to be negatively impacted by commercial import of $A$. mellifera and other managed bees.

\section{SPI-8: climate change: altering pathogen epidemiology to the detriment of pollinators}

In addition to direct and indirect impacts on pollinators, climate change may alter pollinator susceptibility to disease or enhance environmental transmission of pathogens (Natsopoulou et al., 2015). This may change pathogen range, prevalence, epidemiology, and the impact of emerging infectious disease agents on pollinators and pollination. 


\section{SPI-9: destruction of bat roosts worldwide}

Globally, bats face increasing threats (Regan et al., 2015) due to habitat loss, roost destruction, hunting and persecution. As human activities expand into tropical forest areas, destruction of roost sites will increase, while culling is an increasing threat. Bats are important pollinators in tropical forests, savannas, deserts, and for cultivated plants (e.g., agave). The consequences of precipitous declines in bat pollination have not been assessed.

\section{DISCUSSION}

Here we have identified a series of horizon issues, both positive and negative, for pollinators. Interestingly, while some of these have connections to previous causes of pollinator declines, and can be linked to over-arching drivers, such as agriculture and climate change, the policy and practice needed to minimize future threats and maximise future opportunities are largely distinct from current best practice in pollinator conservation.

In addition to their direct effects, the horizon issues identified in this study may also interact to positively and negatively impact pollinators. For example, extreme weather events driven by climate change are likely to influence corporate agriculture, its location, and its spread across the globe, whilst at the same time calling for agricultural practices that develop or support locally specialized pollinators. Such interactions deserve further investigation.

Horizon-scanning projects are, of necessity, limited by the panel make-up and the range of sources they can draw on. We specifically invited panel members from all major geographical regions, and across government research institutes, industry, NGOs, and universities, in order to maximise the breadth of knowledge and experience in our panel. To increase this breadth even further, panel members consulted a wide range of experts. Nevertheless, we acknowledge that an alternative panel make-up could have arrived at a different ordering, or selection of issues. In addition, our selection of issues should not be taken as static. Horizon scanning detects possible future changes about which there is little current evidence (sometimes known as 'weak signals'; Cook et al., 2014). As the future unfolds, new technologies and global change phenomena arise, and so the process should be repeated as an ongoing part of policy and research planning.

Future-proofing pollinators is urgently required, in a world where demand for pollination services is rising at the same time as threats are increasing (Lautenbach et al., 2012; Potts et al., 2010; Vanbergen \& The Insect Pollinator Initiative, 2013). Many of the issues we identified are new developments relating to current problems for pollinators, but some are potential opportunities, or entirely new potential threats (Fig. 1). As indicated in Table 3, for some issues the appropriate policy responses or actions to mitigate negative impacts might be different from those currently discussed or enacted. For example, methods of pollinator management may be needed to control the spread of both plant and insect diseases in future, especially if the number of managed pollinator species, and the distances they are moved, increases. Legislation for pesticide development urgently needs to incorporate chronic and interactive impacts and proper field trials for future pesticides. Early identification of such 
issues provides the opportunity to develop policies and practices to limit negative impacts, or to take advantage of potential positive impacts (Table 3 ).

While all horizon-scanning exercises are limited in their outputs, we believe we have identified current key issues that should be the focus of conservation practitioners, industry, and policy-makers if we are to maintain and benefit from a functional pollinator assemblage at the global scale in the ensuing decades.

\section{ACKNOWLEDGEMENTS}

We would like to thank the following individuals, who were consulted during the first stage of the Horizon Scanning process: C Poole (SANBI, South Africa); P Towers, M Ishii-Eitemann, and E Marquez (Pesticide Action Network, USA); E Mader, A Code, M Vaughan, and S Black (Xerces Society, USA); M Goodwin, P Schaare, L Evans, B Howlett, and C Hall (Plant \& Food Research, New Zealand); T Breeze, R Girling, J Wickens, V Wickens, and J Bishop (University of Reading, UK); V Doublet (University of Exeter, UK); M Husemann, P Theodorou, R Moritz, M Natsopoulou, and A Soro (Halle University, Germany); S Jha (UT Austin, USA); M Lopez-Uribe (North Carolina State University, USA); J Lozier (University of Alabama, USA); G Suwannapong (Burapha University, Thailand); A Zayed (York University, Canada); A Bezerra (Universidade Federal do Ceará, Brazil); V Imperatriz-Fonseca (University of Sao Paolo, Brazil); B Blochtein (Pontifical Catholic University of Rio Grande do Sul, Brazil); S Wiantoro (Museum Zoologicum Bogoriense, Indonesia); J Ollerton (University of Northampton); M Goddard (University of Newcastle); T Ahjohkoski (Bristol City Council); J Zimmermann, E Power, F Hecq, A Delaney, C Owens, and S Kavanagh (Trinity College Dublin, Ireland); M Coulon, E Dubois, V Duquesne, S Franco, M-P Rivière (ANSES, France); F Mutinelli (IZSV, Italy); Brandom Keim (USA); Becky LeAnstey (Environment Agency, UK); A Harmon-Threatt (University of Illinois, USA); Q McFrederick (UC Riverside, USA); M Spivak (University of Minnesota, USA); A-M Klein (University of Freiburg, Germany); M Fox (Environment Agency, UK).

\section{ADDITIONAL INFORMATION AND DECLARATIONS}

\section{Funding}

The Horizon-scanning workshop was supported by Super-B, an EU COST-Action. MJFB was funded by the BBSRC (grant code BB/N000668/1). LVD was funded by the NERC (grant code NE/K015419/1). KCRB was funded by a NERC Knowledge Exchange Fellowship (grant code NE/M006956/1). ABB received funding from Macquarie University and USDA (Grant 58-5342-3-004F). BMF's participation was supported through the National Council for Scientific and Technological Development-Brazil (No. 305126/2013-0). LJL's participation was supported by the Chinese National Natural Science Foundation (No. 31572338) and The Agricultural Science and Technology Innovation Program (CAAS-ASTIP-2016IAR). PN was supported financially by the Vinetum Foundation. DEPs participation was supported through New Zealand's Ministry of Business, Innovation and Employment 
contract no. C11X1309. RJP was funded by DFG grant Pa 632/10. The funders had no role in study design, data collection and analysis, decision to publish, or preparation of the manuscript.

\section{Grant Disclosures}

The following grant information was disclosed by the authors:

Super-B, an EU COST-Action.

BBSRC: BB/N000668/1.

NERC: NE/K015419/1.

NERC Knowledge Exchange Fellowship: NE/M006956/1.

Macquarie University and USDA: 58-5342-3-004F.

National Council for Scientific and Technological Development-Brazil: 305126/2013-0.

Chinese National Natural Science Foundation: 31572338.

Agricultural Science and Technology Innovation Program: CAAS-ASTIP-2016-IAR.

Vinetum Foundation.

New Zealand's Ministry of Business, Innovation and Employment: C11X1309.

DFG: Pa 632/10.

\section{Competing Interests}

The authors declare there are no competing interests.

\section{Author Contributions}

- Mark J.F. Brown, Lynn V. Dicks and Robert J. Paxton conceived and designed the experiments, performed the experiments, analyzed the data, wrote the paper, prepared figures and/or tables, reviewed drafts of the paper.

- Katherine C.R. Baldock, Andrew B. Barron, Marie-Pierre Chauzat, Breno M. Freitas, Dave Goulson, Sarina Jepsen, Claire Kremen, Jilian Li, Peter Neumann, Simon G. Potts, Colleen L. Seymour and Jane C. Stout performed the experiments, analyzed the data, wrote the paper, reviewed drafts of the paper.

- David E. Pattemore and Oliver Schweiger performed the experiments, analyzed the data, wrote the paper, prepared figures and/or tables, reviewed drafts of the paper.

\section{Data Availability}

The following information was supplied regarding data availability:

The raw data has been supplied as Table S1.

\section{Supplemental Information}

Supplemental information for this article can be found online at http://dx.doi.org/10.7717/ peerj.2249\#supplemental-information.

\section{REFERENCES}

Baldock KCR, Goddard MA, Hicks DM, Kunin WE, Mitschunas N, Osgathorpe LM, Potts SG, Robertson KM, Scott AV, Stone GN, Vaughamm IP, Memmott J. 2015. Where is the UK's pollinator biodiversity? The importance of urban 
areas for flower-visiting insects. Proceedings of the Royal Society B 282:20142849

DOI 10.1098/rspb.2014.2849.

Bass C, Denholm I, Williamson MS, Nauen R. 2015. The global status of insect resistance to neonicotinoid insecticides. Pesticide Biochemistry and Physiology 121:78-87 DOI 10.1016/j.pestbp.2015.04.004.

Batáry P, Dicks LV, Kleijn D, Sutherl WJ. 2015. The role of agri-environment schemes in conservation and environmental management. Conservation Biology 29:1006-1016 DOI 10.1111/cobi.12536.

Carvalheiro LG, Kunin WE, Keil P, Aguirre-Gutiérrez J, Ellis WN, Fox R, Groom Q, Hennekens S, Van Landuyt W, Maes D, Van de Meutter F, Michez D, Rasmont P, Ode B, Potts SG, Reemer M, Roberts SPM, Schaminée, De Vries MFW, Biemeijer JC. 2013. Species richness declines and biotic homogenization have slowed down for NW-European pollinators and plants. Ecology Letters 16:870-878 DOI 10.1111/ele.12121.

Civitello DJ, Cohen J, Fatima H, Halstead NT, Liriano J, McMahon TA, Ortega CN, Sauer EL, Sehgal T, Young S, Rohr JR. 2015. Biodiversity inhibits parasites: broad evidence for the dilution effect. Proceedings of the National Academy of Sciences of the United States of America 112:8667-8671 DOI 10.1073/pnas.1506279112.

Cook CN, Inayatullah S, Burgman MA, Sutherland WJ, Wintle BA. 2014. Strategic foresight: how planning for the unpredictable can improve environmental decisionmaking. Trends in Ecology and Evolution 29:531-541 DOI 10.1016/j.tree.2014.07.005.

Delaplane KS, Mayer DF. 2000. Crop Pollination by Bees. Wallingford: CABI Publishing.

Dicks L. 2013. Bees, lies and evidence-based policy. Nature 494:283-283 DOI 10.1038/494283a.

Di Prisco G, Cavaliere V, Annoscia D, Varricchio P, Caprio E, Nazzi F, Gargiulo G, Pennacchio F. 2013. Neonicotinoid clothianidi adversely affects insect immunity and promotes replication of a viral pathogen in honey bees. Proceedings of the National Academy of Sciences of the United States of America 110:18466-18471 DOI 10.1073/pnas.1314923110.

Drechsler M, Eppink FV, Wätzold F. 2011. Does proactive biodiversity conservation save costs? Biodiversity Conservation 20:1045-1055 DOI 10.1007/s10531-011-0013-4.

Fox AD, Jónsson JE, Aarvak T, Bregnballe T, Christensen TK, Clausen KK, Clausen P, Dalby L, Holm TE, Pav́on-Jordan D, Laursen K, Lehikoinen A, Lorentsen S-H, Møller AP, Nordström M, Öst M, Söderquist P, Therkildsen OR. 2015. Current and potential threats to Nordic duck populations-a horizon scanning exercise. Annales Zoologici Fennici 52:193-220 DOI 10.5735/086.052.0404.

Free JB. 1993. Insect pollination of crops. Second edition. London: Academic Press.

Fürst MA, McMahon DP, Osborne JL, Paxton RJ, Brown MJF. 2014. Disease associations between honeybees and bumblebees as a threat to wild pollinators. Nature 506:364-366 DOI 10.1038/nature12977.

Gilbert N. 2014. 'Life on Earth' project gets underway. Nature 510:455.

Godfray HCJ, Blacquière T, Field LM, Hails RS, Potts SG, Raine NE, Vanbergen AJ, McLean AR. 2015. A restatement of recent advances in the natural science evidence 
base concerning neonicotinoid insecticides and insect pollinators. Proceedings of the Royal Society B 282:20151821 DOI 10.1098/rspb.2015.1821.

Harrison RD. 2000. Repercussions of El Nino: drought causes extinction and the breakdown of mutualism in Borneo. Proceedings of the Royal Society B 267:911-915 DOI 10.1098/rspb.2000.1089.

He WZ, Wu K, Shao Y, Zhao Z, Zhang B, Zheng Y. 2013. Exotic bumblebee may be a risk for Bombus resources in China. Apiculture of China 64:38-40 [In Chinese with English summary].

Hulme PE, Pysek P, Nentwig W, Vilà M. 2009. Will threat of biological invasions unite the European Union? Science 324:40-41 DOI 10.1126/science.1171111.

IPBES. 2016. Pollination. Available at http://www.ipbes.net/work-programme/pollination. IPCC Summary for Policymakers. 2013. Stocker TF, Qin D, Plattner G-K, Tignor M, Allen SK, Boschung J, Nauels A, Xia Y, Bex V, Midgley PM, eds. Climate change 2013: the physical science basis. contribution of working group 1 to the fifth assessment report of the intergovernmental panel on climate change. Cambridge: Cambridge University Press.

Kennedy CM, Lonsdorf E, Neel MC, Williams NM, Ricketts TH, Winfree R, Bommarco R, Brittain C, Burley AL, Cariveau D, Carvalheiro LG, Chacoff NP, Cunningham SA, Danforth BN, Dudenhöffer JH, Elle E, Gaines HR, Gratton C, Garibaldi LA, Holzschuh A, Isaacs R, Javorek SK, Jha S, Klein AM, Krewenka K, Mandelik Y, Mayfield MM, Morandin L, Neame LA, Otieno M, Park M, Potts SG, Rundlöf M, Saez A, Steffan-Dewenter I, Taki H, Viana BF, Westphal C, Wilson JK, Greenleaf SS, Kremen C. 2013. A global quantitative synthesis of local and landscape effects on wild bee pollinators in agroecosystems. Ecology Letters 16:584-599 DOI 10.1111/ele.12082.

Kennicutt MC, Chown SL, Cassano JJ, Liggett D, Massom R, Peck LS, Rintoul SR, Storey J, Vaughan DG, Wilson TJ, Suterl WJ. 2014. Polar research: six priorities for Antarctic science. Nature 512:23-25.

Kerr JT, Pindar A, Galpern P, Packer L, Potts SG, Roberts SM, Rasmont P, Schweiger O, Colla SR, Richardson LL, Wagner DL, Gall LF, Sikes DS, Pantoja A. 2015. Climate change impacts on bumblebees converge across continents. Science 349:177-180 DOI 10.1126/science.aaa7031.

Klein A-M, Vaissière BE, Cane JH, Steffan-Dewenter I, Cunningham SA, Kremen C, Tscharntke T. 2007. Importance of pollinators in changing landscapes for world crops. Proceedings of the Royal Society B 274:303-313 DOI 10.1098/rspb.2006.3721.

Laurance WF, Clements GR, Sloan S, O’Connell CS, Mueller ND, Goosem M, Venter O, Edwards DP, Phalan B, Balmford A, Van Der Ree R, Arrea IB. 2014. A global strategy for road building. Nature 513:229-232.

Lautenbach S, Seppelt R, Liebscher J, Dormann CF. 2012. Spatial and temporal trends of global pollination benefit. PLoS ONE 7:e35954 DOI 10.1371/journal.pone.0035954.

Manley R, Boots M, Wilfert L. 2015. Emerging viral disease risk to pollinating insects: ecological, evolutionary and anthropogenic factors. Journal of Applied Ecology 52:331-340 DOI 10.1111/1365-2664.12385. 
Mazzucato A, Cellini F, Bouzayen M, Zouine M, Mila I, Minoia S, Petrozza A, Picarella ME, Ruiu F, Carriero F. 2015. A TILLING allele of the tomato Aux/IAA9 gene offers new insights into fruit set mechanisms and perspectives for breeding seedless tomatoes. Molecular Breeding 35:Article 22 DOI 10.1007/s11032-015-0222-8.

McArt SH, Koch H, Irwin RE, Adler LS. 2014. Arranging the bouquet of disease: floral traits and the transmission of plant and animal pathogens. Ecology Letters 17:624-636 DOI 10.1111/ele.12257.

McMahon DP, Fürst MA, Casper J, Theodorou P, Brown MJF, Paxton RJ. 2015. A sting in the spit: widespread cross-infection of multiple RNA viruses across wild and managed bees. Journal of Animal Ecology 84:615-624 DOI 10.1111/1365-2656.12345.

Morales C, Arbetman MP, Cameron SA, Aizen MA. 2013. Rapid ecological replacement of a native bumble bee by invasive species. Frontiers in Ecology and Environment 11:529-534 DOI 10.1890/120321.

Muratet A, Fontaine B. 2015. Contrasting impacts of pesticides on butterflies and bumblebees in private gardens in France. Biological Conservation 182:148-154 DOI 10.1016/j.biocon.2014.11.045.

Natsopoulou ME, McMahon DP, Doublet V, Bryden J, Paxton RJ. 2015. Interspecific competition in honeybee intracellular gut parasites is asymmetric and favours the spread of an emerging infectious disease. Proceedings of the Royal Society $B$ 282:20141896 DOI 10.1098/rspb.2014.1896.

Oliver TH, Marshall HH, Morecroft MD, Brereton T, Prudhomme C, Huntingford C. 2015. Interacting effects of climate change and habitat fragmentation on droughtsensitive butterflies. Nature Climate Change 5:941-945 DOI 10.1038/nclimate2746.

Ollerton J, Winfree R, Tarrant S. 2011. How many flowering plants are pollinated by animals? Oikos 120:321-326 DOI 10.1111/j.1600-0706.2010.18644.x.

Pettis JS, Lichtenberg EM, Andree M, Stitzinger J, Rose R, VanEngelsdorp D. 2013. Crop pollination exposes honey bees to pesticides which alters their susceptibility to the gut pathogen Nosema ceranae. PLoS ONE 8(7):e70182 DOI 10.1371/journal.pone.0070182.

Potts SG, Biesmeijer JC, Kremen C, Neumann P, Schweiger O, Kunin WE. 2010. Global pollinator declines: trends, impacts and drivers. Trends in Ecology and Evolution 25:345-353 DOI 10.1016/j.tree.2010.01.007.

Rasmont P, Iserbyt S. 2012. The bumblebees scarcity syndrome: are heat waves leading to local extinctions of bumblebees (Hymenoptera: Apidae: Bombus)? Annales de la Société Entomologique de France 48:275-280.

Regan EC, Santini L, Ingwall-King L, Hoffmann M, Rondinini C, Symes A, Taylor J, Butchart SHM. 2015. Global trends in the status of bird and mammal pollinators. Conservation Letters 8:397-403 DOI 10.1111/conl.12162.

Roberts JMK, Anderson DL, Tay WT. 2015. Multiple host shifts by the emerging honeybee parasite, Varroa jacobsoni. Molecular Ecology 24:2379-2391

DOI 10.1111/mec.13185.

Roy HE, Peyton J, Aldridge DC, Bantock T, Blackburn TM, Britton R, Clark P, Cook E, Dehnen-Schmutz K, Dines T, Dobson M, Edwards F, Harrower C, Harvey 
MC, Minchin D, Noble DF, Parrott D, Pocock MJ, Preston CD, Roy S, Salisbury A, Schönrogge K, Sewell J, Shaw RH, Stebbing P, Stewart AJ, Walker KJ. 2014. Horizon scanning for invasive alien species with the potential to threaten biodiversity in Great Britain. Global Change Biology 20:3859-3871 DOI 10.1111/gcb.12603.

Rundlöff M, Andersson GKS, Bommarco R, Fries I, Hederström V, Herbertsson L, Jonsson O, Klatt BK, Pedersen TR, Yourstone J, Smith HG. 2015. Seed coating with a neonicotinoid insecticide negatively affects wild bees. Nature 521:77-80 DOI 10.1038/nature14420.

Sekhon BS. 2014. Nanotechnology in agri-food production: an overview. Nanotechnology Science and Applications 7:31-53 DOI 10.2147/NSA.S39406.

Simon-Delso N, Amaral-Rogers V, Belzunces LP, Bonmatin JM, Chagnon M, Downs C, Furlan L, Gibbons DW, Giorio C, Girolami V, Goulson D, Kreutzweiser DP, Krupke CH, Liess M, Long E, McField M, Mineau P, Mithcell EAD, Morrissey CA, Noome DA, Pisa L, Settele J, Stark JD, Tapparo A, Van Dyck H, Van Praagh J, Van de Sluijs JP, Whitehorn PR, Wiemers M. 2015. System insecticides (neonicotinoids and fipronil): trends, uses, mode of action and metabolites. Environmental Science and Pollution Research 22:5-34 DOI 10.1007/s11356-014-3470-y.

Sparks TC, Watson GB, Loso MR, Geng C, Babcock JM, Thomas JD. 2013. Sulfoxaflor and the sulfoximine insecticides: chemistry, mode of action and basis for efficacy on resistant insects. Pesticide Biochemistry and Physiology 107:1-7 DOI 10.1016/j.pestbp.2013.05.014.

Stout JC, Morales CL. 2009. Ecological impacts of invasive alien species on bees. Apidologie 40:388-409 DOI 10.1051/apido/2009023.

Sutherland WJ, Broad S, Caine J, Clout M, Dicks LV, Doran H, Entwistle AC, Fleishman E, Gibbons DW, Keim B, LeAnstey B, Lickorish FA, Markillie P, Monk KA, Mortimer D, Ockendon N, Pearce-Higgins JW, Peck SL, Pretty J, Rockström J, Spalding MD, Tonneijck FH, Wintle BC, Wright KE. 2016. Horizon scan of global conservation issues for 2016. Trends in Ecology and Evolution 31:44-53 DOI 10.1016/j.tree.2015.11.007.

Takkis K, Tscheulin T, Tsalkatis P, Petanidou T. 2015. Climate change reduces nectar secretion in two common Mediterranean plants. AoB PLANTS 7:Article plv111 DOI 10.1093/aobpla/plv111.

Vanbergen AJ, The Insect Pollinator Initiative. 2013. Threats to an ecosystem service: pressures on pollinators. Frontiers in Ecology and Environment 11:251-259 DOI 10.1890/120126.

Wilfert L, Long G, Leggett HC, Schmid-Hempel P, Butlin R, Martin SJ, Boots M. 2016. Deformed wing virus is a recent global epidemic in honeybees driven by Varroa mites. Science 351:594-597 DOI 10.1126/science.aac9976.

Worldwatch Institute. 2013. Agri-businesses consolidate power. Available at http://www. worldwatch.org/node/5468. 